of Meteorology in 1959 following on a recommendation of the Special Committee for Antarctic Research at its Moscow meeting in 1958. It has now been operating for three years and is staffed by five professional meteorologists from Australia, Argentina, France and the United States, constituting a truly international team. The programme of work undertakes to analyse circumpolar 700,500 and $300 \mathrm{mb}$. constant pressure charts over the area south of $60^{\circ}$ S. at 00 and 12 G.M.T. daily. At 00 G.M.T. the analyses are extended northwards to about $30^{\circ} \mathrm{S}$. The charts are later re-analysed after the entry of new synoptic data. The final product is microfilmed. A library of data is thus being built for future research workers engaged in studies of the meteorology of the southern hemisphere and of the global atmospheric circulation. The hope has been expressed that the International Antarctic Analysis Centre may itself soon partake in such research.

\section{The Pengelly Cave Research Centre}

The Pengelly Cave Research Centre was founded on March 31, 1962, at a joint meeting of the Society for the Promotion of Nature Reserves, the Devon Naturalists' Trust and the Devon Spelæological Society (News for Naturalists, 4, No. 1; July 1962). The headquarters of this new Centre, which has been named after William Pengelly, the pioneer nineteenth-century excavator of Kent's Cavern, are at Higher Kiln Quarry, Buckfastleigh, purchased in October, 1961, by the Society for the Promotion of Nature Reserves, and is to be developed for the furtherance of cave research in Britain. The site is already well known to cavers and naturalists as containing the entrances to Reed's and Joint Mitnor Caves. The acquisition of Higher Kiln Quarry by a scientific organization provides an opportunity, for the first time, of developing a much-needed cave research and demonstration centre in Britain. The site is exceptionally well suited for this purpose, for not only is it easily accessible, but it also contains a variety of features, usually available only over a distance of several miles.

At the present time Britain lags behind countries such as France (which already has a well-equipped underground laboratory at Moulis, in the Pyrenees), Belgium, Yugoslavia, the United States and Cuba in the facilities for cavern research which it has to offer to spelæologists. There is no means whereby the naturalist or student who is not a spelæologist can obtain first-hand experience of the natural history of caves. Moreover, the great increase in the popularity of caving as a sport in Great Britain presents a serious threat to the preservation of much of scientific importance that the British caves contain unless steps are taken to educate cavers. One of the objects of the Centre will be the development of conservation-mindedness.

\section{National Parks of Canada}

Two of Canada's National Parks are discussed in booklets issued by the Geological Survey of Canada (Canada: Department of Mines and Technical Surveys. Geological Survey of Canada. Miscellaneous Report No. 4: Yoho National Park-the Mountains, the Rocks, the Scenery. Pp. vi+107. 1 dollar. No. 5: Cape Breton Highlands National Park-where the Mountains Meet the Sea. By David M. Baird. Pp. vi +65 . 75 cents. Ottawa: Director, Geological Survey of Canada, 1962). Both have been prepared by David B. Baird, who has taken some outstanding photographs to add to the attraction of the booklets. The text has been prepared with such commendable skill that either booklet would serve as an introduction to petrology as well as a helpful guide to some of Canada's outstanding scenery.

\section{Biology and Human Affairs}

A NOVEL approach to food production and storage in plants is described in an outstanding editorial comment in Biology and Human Affairs (27, No. 3; Summer 1962). Among the other articles is one on crop plants by N. W. Simmonds, an account of his work on the ecology of ants by J. W. Siddorn, the place of mathematics in biology by M. J. R. Heeley, and various aspects of human learning and understanding by Dr. E. C. Poulton. The journal is published by the British Social Biology Council, 69 Eccleston Square, London, S.W.1.

\section{Space Science Reviews}

The first issue of a new international quarterly journal Space Science Reviews recently appeared (1, No. 1, June, 1962. Edited by C. de Jager. Pp. 154. Published quarterly. (Dordrecht: D. Reidel Publish. ing Company, 1962.) Subscription price 150 florins, 42 dollars per volume of four issues.) The editor-inchief, C. de Jager, of the University of Utrecht, explains in the introduction that the journal will not include original research papers, but will consist of invited review articles on particular aspects of space science and technology. Each issue will run to about 180 pages, containing between 5 and 8 contributions. Space research, as it expands, is covering an everbroadening area of science, and the journal should meet the widely acknowledged need for authoritative and up-to-date reviews. The first issue has 6 excellent contributions. First, H. Wexler discusses the results obtained from the Tiros weather-satellites. Then follow four articles on strong solar disturbances and their effects: H. Carmichael describes the highenergy solar-particle events of 1959-61; E. N. Parker and T. Gold (in separate articles) discuss the mechanism of geomagnetic storms; D. C. Rose and S. Ziauddin consider the polar cap absorption effect. Finally, T. M. Donahue reviews the possible sources of the Lyman- $x$ radiation observed in the night sky.

\section{Radioactivity in Drinking Water}

Investigations by the Government Chemist show there was no appreciable increase or decrease in amounts of radiostrontium and radiocæsium in United Kingdom drinking water during 1961 (Ministry of Housing and Local Government; Scottish Development Department; Ministry of Health and Local Government, Northern Ireland. Radiostrontium and Radiocaesium in Drinking Water in the United Kingdom-1961 Results. Pp. 19. London: H.M.S.O., 1962. 1s. $6 d$. net). The investigations do not cover samples taken in 1962, but the evidence so far availablo indicates that the Russian nuclear tests in the autumn of 1961 are unlikely to have caused higher levels of strontium-90 in drinking water this yoar than during 1959. In 1961 drinking water contributed less than 5 per cent of the total amount of strontium-90 in the average diet; the amount of cæsium-137 in drinking water was about half the quantity of strontium-90. Details of these and other 